\title{
Mountains of Asia A REGIONAL INVENTORY
}
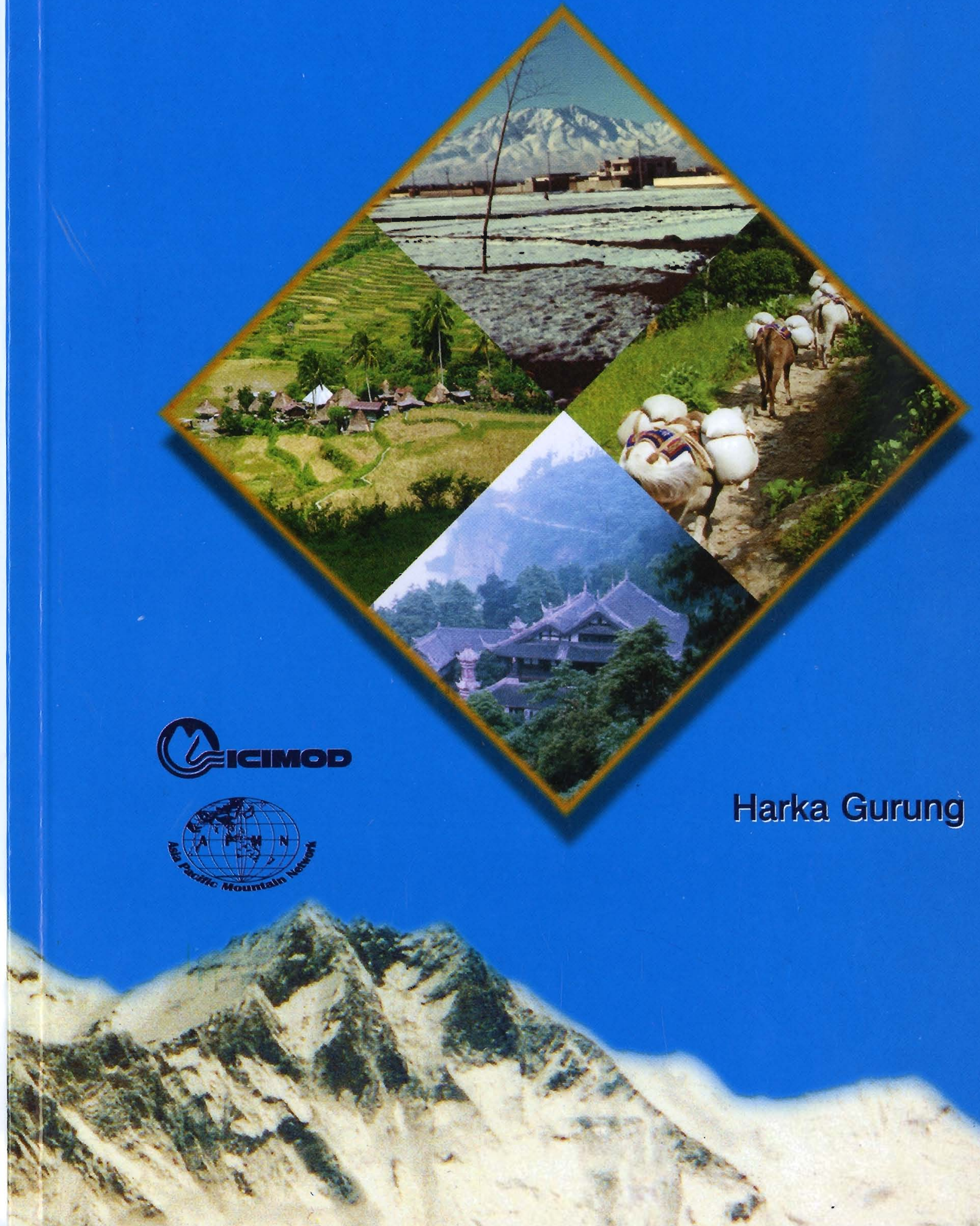


\section{(c)}

International Centre for Integrated Mountain Development

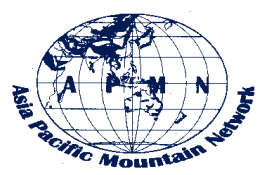

Asia Pacific Mountain Network

\section{Mountains of Asia A Regional Inventory}

Harka Gurung 
Copyright (C) 1999

International Centre for Integrated Mountain Development

All rights reserved

ISBN: 9291159360

\section{Published by}

International Centre for Integrated Mountain Development

GPO Box 3226

Kathmandu, Nepal

\section{Photo Credits}

Snow in Kabul - Madhukar Rana (top)

Transport by mule, Solukhumbu, Nepal - Hilary Lucas (right)

Taoist monastry, Sichuan, China - Author (bottom)

Banaue terraces, The Philippines - Author (left)

The Everest panorama - Hilary Lucas (across cover)

\section{All map legends are as per Figure 1 and as below.}

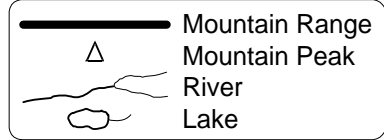

\section{Layout by}

Sushil Man Joshi

\section{Typesetting at}

ICIMOD Publications' Unit

The views and interpretations in this paper are those of the author(s). They are not attributable to the International Centre for Integrated Mountain Development (ICIMOD) and do not imply the expression of any opinion concerning the legal status of any country, territory, city or area of its authorities, or concerning the delimitation of its frontiers or boundaries. 


\section{Preface}

$\mathrm{M}$

ountains have impressed and fascinated men by their majesty and mystery. They also constitute the frontier of human occupancy as the home of ethnic minorities. Of all the continents, it is Asia that has a profusion of stupendous mountain ranges - including their hill extensions. It would be an immense task to grasp and synthesise such a vast physiographic personality. Thus, what this monograph has attempted to produce is a mere prolegomena towards providing an overview of the regional setting along with physical, cultural, and economic aspects. The text is supplemented with regional maps and photographs produced by the author, and with additional photographs contributed by different individuals working in these regions.

I wish to thank ICIMOD for giving me this opportunity to learn more about the mountains. Therefore, I would like to express my appreciation to Mr. Egbert Pelinck, Director General, for the assignment and Dr. Mahesh Banskota, Deputy Director General, for the necessary support. Kathmandu is not the ideal location to search for literature on mountains beyond the Hindu Kush-Himalayas. This made me venture beyond, to Bangkok and Kuala Lumpur. In Bangkok, Mr. Kiran Pyakuryal made it possible for me to use the ESCAP Library, despite it being closed for the ESCAP's annual session. In Kuala Lumpur, Ms. Siti Rafeah Shamsudin of the APDC Library was most helpful. The regional maps were fine-tuned by Mr. A. K. Thaku of ICIMOD. Mr. Chandra Man Singh of New ERA typed the draft. I wish to thank them for their cooperation. 


\section{Foreword}

A s the International Centre for Integrated Mountain Development, ICIMOD's foremost focus has been and is the Hindu Kush-Himalayas. Notwithstanding, the Centre has always acknowledged the linkages and interfaces that exist between these mountains and other ranges in Asia. For this reason, the Centre had, with the help of the Swiss Development Cooperation (SDC), established the Asia Pacific Mountain Network (APMN) in early 1996. It is through this network that the Centre maintains important linkages through meaningful interfacing with other Asian mountain regions. One example of this has been the successful Council for Sustainable Development of Central Asia (CoDoCA) conferences on the mountainous countries of Central Asia.

This current document is a result of ICIMOD's search for linkages-ways of reaching out through partnerships to other mountain areas in Asia, so that we can share the most useful areas of our work with the mountain peoples on this continent and beyond. It provides a useful overview and insight into the mountain regions as dynamic entities in themselves. A glance through its pages gives readers some idea of the immense variety and richness of species, including the human species, that inhabit these interesting and challenging areas of the earth's surface. They have much in common and much that is unique to specific ranges.

ICIMOD would like to thank Dr. Harka Gurung for agreeing to take on such an unwieldy task in such a short period of time. I would also like to take this opportunity to thank the APMN programme of ICIMOD for helping to facilitate its publication in print and on the APMN section on Internet. The ICIMOD Publications' team has responded to the idea of having a printed version ready for the Mountain Forum conference in Cuzco, Peru, by working with alacrity to edit and process the document for printing.

We hope to show that all mountains of Asia have their commonalties, but we also hope to emphasise their uniqueness and the value they do bring and will bring to life on earth in the $21^{\text {st }}$ century.

Egbert Pelinck

Director General 


\section{Abstract}

7 his book provides a description of Asian mountain and hill ranges according to geographic grouping. There is a heavy emphasis on the Himalayas since the text is based on documentation available in the Himalayan region, given the fact that travel outside the Hindu KushHimalayas was limited within the specific time frame. Nevertheless, the author has used his ingenuity to supplement the information on other ranges from many sources, including internet. He describes 110 mountain and hill ranges in 37 countries. A qualitative account of salient features is given. The mountains of Asia have been divided into six regions; namely, South Asia, West Asia, Central Asia, North-East Asia, South-East Asia, and Australasia. This book will be of great interest to those who are unfamiliar with the mountain areas of Asia and to those who are familiar but need ready reference to them. It has a valuable, comprehensive bibliography and a mountain glossary of indigenous terms for physical features and land use in 35 languages. Each region has its own map focussing on its mountain ranges. 


\section{Table of Contents}

Preface

Foreword

Abstract

1 Introduction 1

1.1 Purpose 1

1.2 Definition 2

1.3 Asian Context 3

2 South Asia $\quad 5$

2.1 The Karakoram 5

2.2 The Himalaya $\quad 7$

2.3 The North-East 13

2.4 The Peninsula 13

2.5 The North-West 15

3 West Asia $\quad 19$

3.1 The Iran Plateau $\quad 19$

3.2 Trans-Caucasia 20

$\begin{array}{lll}3.3 & \text { Anatolia } & 21\end{array}$

3.4 Arabia $\quad 21$

4 Central Asia $\quad 25$

4.1 The Tibetan Plateau $\quad 25$

4.2 Hengduan 28

$\begin{array}{ll}4.3 \text { Kun Lun } & 29\end{array}$

4.4 The Pamir 31

4.5 Tien Shan $\quad 32$

$\begin{array}{lll}4.6 & \text { Altai } & 33\end{array}$

4.7 The Urals 33 
5.1 Eastern Russia $\quad 37$

5.2 North and East China $\quad 40$

5.3 The Korean Peninsula 41

5.4 The Japanese Archipelago 42

$6 \quad$ South-East Asia $\quad 47$

6.1 The Continental Interior $\quad 47$

6.2 Peninsular 50

$\begin{array}{lll}6.3 & \text { Insular } & 50\end{array}$

$\begin{array}{lll}7 & \text { Australasia } & \mathbf{5 7}\end{array}$

7.1 New Guinea $\quad 57$

$\begin{array}{lll}7.2 & \text { Australia } & 59\end{array}$

$\begin{array}{lll}7.3 & \text { New Zealand } & 60\end{array}$

$8 \quad$ Thematic Overview $\quad 65$

8.1 Physical Environment $\quad 65$

$\begin{array}{ll}8.2 & \text { Cultural Diversity } \\ \end{array}$

$\begin{array}{ll}\text { Selected Bibliography } & 73\end{array}$

$\begin{array}{lll}\text { A } & \text { General } & 73\end{array}$

B South Asia $\quad 74$

C West Asia $\quad 76$

$\begin{array}{ll}\text { D Central Asia } & 76\end{array}$

$\begin{array}{ll}\text { E North-East Asia } & 78\end{array}$

$\begin{array}{ll}\text { F South-East Asoa } & 78\end{array}$

$\begin{array}{ll}\text { G Australasia } & 79\end{array}$

$\begin{array}{ll}\text { Appendix } 1 \text { Mountain Glossary } & 81\end{array}$

Appendix 2 Mountain Areas and Minority Peoples of China $\quad 85$ 